\title{
Ancient Routes, New Destinations: Roman Road Via Sebaste as a Thematic Cultural Route
}

\author{
Mustafa Arslan \\ Assistant Professor, Selcuk University \\ Beysehir Ali Akkanat Faculty of Tourism \\ E-mail:muarslan@selcuk.edu.tr
}

\section{Doi:10.5901/mjss.2013.v4n10p660}

\section{Abstract}

Thematic cultural routes are becoming more important nowadays in Turkey's tourism. There are tens of walking routes in Anatolia. These routes are generally between uplands in different regions. Among these routes, there are long distance footpaths based on ancient roads. These are The Lycian Way-509 km, St. Paul Trail-410 km and Hittite Way which is also suitable for cycling-385 km. These routes are all waymarked and pass from historical places from different cultures and periods such as Hittite, Hellenistic, Roman and Turkish periods. St. Paul Trail was marked by Kate Clow and follows the route of St. Paul's missionary journey. This trail generally uses western branch of Via Sebaste which was built in 6 B.C by Roman emperor Augustus. Starting point of Via Sebaste is Pisidian Antioch and it has two courses. Western course has already been marked and combined with the route of St. Paul's journey and opened to tourism for back packers. Eastern course is not mentioned very much although it has got more touristic attraction sites. A traveller is going to be able to see the biggest fresh water lake of Turkey, two big stork colonies, prehistoric mounds, monuments from Hittite period, Seljukian mosque, caravanserai and palace and caves of Seydişehir-Derebucak regions on this route. After passing Taurus Mountain ridge the main road reaches to ancient harbour city of Side. Apart from this main route the road has many byways reaching mountainous regions since it was built by military requirements Not only the main route of Via Sebaste but all branches should be determined carefully for tourism purposes. Localising all the road system as a whole is going to enrich tourism facilities. Identifying all byways of Via Sebaste is going to offer many choices for the visitors with its multiple starting and finishing points. This road is a candidate new thematic cultural route with its ornithology, speleology, gastronomy, fishing, cycling opportunities. The aim of this paper is to introduce the Roman road "Via Sebaste" and natural-historical beauties along the road.

Keywords: Via Sebaste, Thematic Cultural Routes, Tourism

\section{Introduction}

Ecotourism is a "responsible travel to natural areas that conserves the environment and improves the well-being of local people". This kind of tourism has become very popular nowadays. In addition to its popularity, UN declared 2002 as the International year of Ecotourism. For further support for sustainable development UN declared 2011 as the International Year of Forests. Activities such as; Ornithology, trekking, Highland Tourism, Cave Tourism, Hunting, Diving, Air Sports, Angling, Horse Riding, Cycling, Botany Tourism, Photography, Caravan Tourism can be defined as kinds of ecotourism (Erdoğan 2003:120).

Lake Beysehir (Figure 1) is situated in two national parks, Lake Beysehir and Kızıldag National Parks. With its natural sources and historical findings nearly all the activities mentioned above can be practised in the lake area and its vicinity. Founded in 1993 Lake Beysehir National Park is the largest national park in Turkey with its 88.750 ha area. Nearby national park, Kızıldag had been founded in 1969 on an area of 2.316 ha and later it was extended to 59.400 ha in 1993. Area of Lake Beysehir is $650 \mathrm{~km}^{2}$ and it is the biggest fresh water lake in Turkey. Wetlands and reedy places around the lake provide a very suitable environment for water birds and other species. Lake Beysehir is a resting place for migratory birds in autumn and spring and also a nesting area for the local birds in summers. Lake Beysehir has been a very important place not only for the birds but also the societies settled in or around the lake. Because there are more than 30 islands in the lake and 15 of them are suitable for settlement. History of the region goes back to as old as Neolithic Age and historical development of the region has continued up to now. Lake Beysehir region has many cultural and historical items representing various ages. And Via Sebaste is a very beautiful route which will be able to combine these assets. 


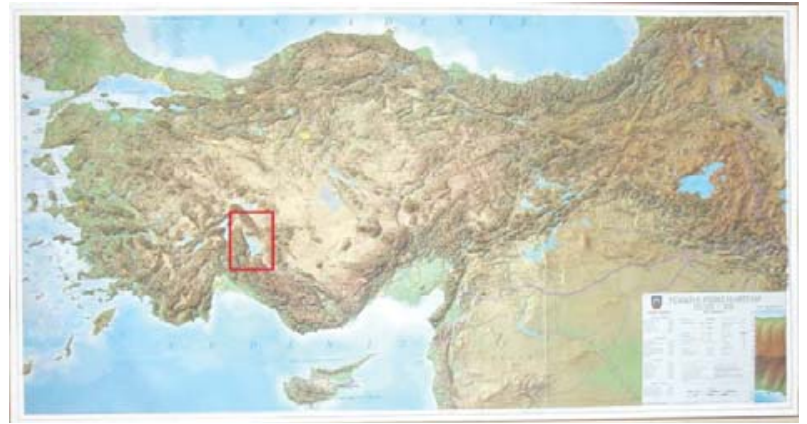

Figure 1: Lake Beysehir in Turkey.

\section{Via Sebaste Way}

Via Sebaste (Figure 2) is a road network which was built by Augustus in $6 \mathrm{BC}$ to control the Taurus tribes especially the Homonadeis whose mainstay was piracy and to provide communication among Augustan colonies established in the region with defence purposes (Cronin 1902: 109; Levick 1965: 54; Robinson 1924: 436). Via Sebaste does not have one branch but many sideways reaching different parts of the region. This road network has only one name since it was built in the same period with the same purposes (Ramsay 1916: 87). These roads which needed high knowledge of engineering (Mitchell 1995: 126) were generally stone paved (Bahar 2006: 96). Parts of the roads passing mountainous regions are in good condition due to its strong construction and furthermore they have been used by nomadic Turkish tribes nearly until today. Use of these road systems by locals until today has provided some regular reparations and by the help of these reparations the system was not covered by earth and remained on the ground.

By starting from Pisidian Antioch (Yalvac), Via Sebaste reaches Neapolis (Sarkikaraağaç) by following nearly the same course of today's highway. Then it forks near Huyuk. Left part leads to Iconium (Konya) and right part reaches Misthia (Beysehir) via Kireli. The evidence of the course of right part is a mile stone found in Kireli. Via Sebaste passes Beysehir on Carsamba Spring on which there is a stone bridge from Ottoman period. Cronin had visited Beysehir before the Ottoman Bridge was built and reported stones of Roman Period (Cronin 1902: 105-9). Soon after, Ramsay visited Beysehir after the Ottoman Bridge had been built and he reported the same stones of an older bridge from the same period as well (Ramsay 1924: 200). The road finally reaches notorious ancient city Side via Gembos Plain.

Levick proposed that a side way of Via Sebaste might reach to Adada from a defile of Mount Anamas by following western shores of Lake Beysehir after Sarkikaraagac (Levick 1967: 15).

The information mentioned above proves that Via Sebaste nearly surrounds all around Lake Beysehir. The only part which Via Sebaste does not pass is between Yesildag and Kurucuova. Transportation by modern road between these two towns is very hard even today due to geographical conditions. But there is a link between Kurucuova and Dumanlı which was used in the past very effectively. Although there is lack of information whether this road was a part of Via Sebaste during Roman period, it is possible that it might be a side way of the road network. Archaeological findings which could be dated to Roman period on this road lead the writer to consider the presence of an ancient road part. But it is clear that this part of the road has been used since Turkish occupation by nomadic Turkish people even if it was not an ancient route. Close relations between Mediterranean people and Beysehir people prove the active use of this road.

\section{Historical Places on Via Sebaste}

There are a lot of mounds, and ruins in Beysehir on the route of Via Sebaste as there are a lot of them in every corner of Turkey. The interesting thing about Via Sebaste is the historical places on it. They are very famous and unique in terms of their features. A visitor will be able to see these places without leaving the route.

Starting point of Via Sebaste is mentioned above but trekking should start from Beysehir since this point has more advantages than Antiocheia in terms of accommodation and transportation. 


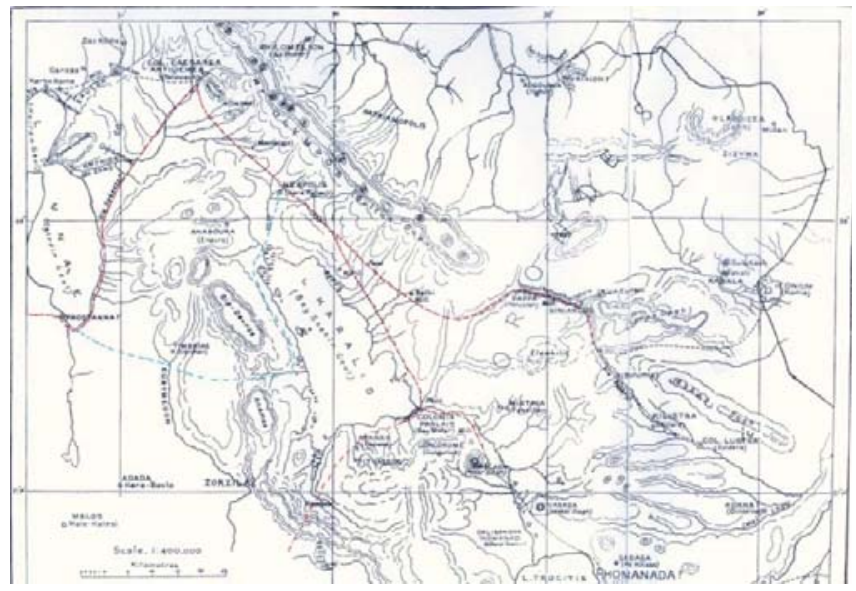

Figure 2: Route of Via Sebaste during 6 B.C. Blue marked route is Levick's proposal. (Ramsay 1920)

\subsection{Esrefoglu Mosque, Historical Stone Bridge, Turkish Bath and Ismail Aga Madrasah}

Esrefoglu Mosque is situated in İcerisehir, the oldest district of Beysehir (Picture 1). As it is understood from its name, this mosque was built during Esrefoglu Principality in 1299 (Konyalı 1991: 225) and survived up to now by keeping its original form. It's also famous for its woodworking.

Another historical building contemporary with the mosques is Bedesten or literarily the Covered Bazaar. It is still in use and used for exhibitions and meetings. Next to Bazaar is the Turkish Bath and it is also from the principality era and it is also in use for public domain. İsmail Aga Madrasah shares the same square with these historical buildings and was newly restored. The newest historical building among these is the stone bridge of Beysehir. It is from Ottoman period and was a part of first irrigation Project of Ottoman Empire.

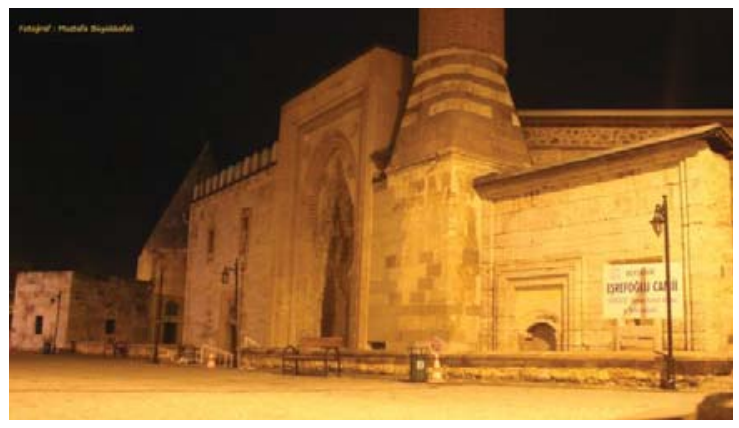

Picture 1: Esrefoglu Mosque (Büyükkafalı 2013)

\subsection{Eflatunpinar and Wolf's Cradle Hittite Monuments}

Eflatunpinar is a Hittite Monument in Sadikhaci Town of Beysehir County (Picture 2). It was built next to a spring and cosists of 19 huge stones. These stones were placed vertically and horizontally to form a facade. It has a rectangular shape with $7 \mathrm{~m}$ length and $5 \mathrm{~m}$ width. This monument is dated to Tuthalia IV. by historians (Darga 1992: 186, Yegül 2009: 101) Wolf's Cradle is another Hittite period monument in the area (Picture 3). It is the biggest monolithic monument in Turkey and weighs 70 tons. A major god is relieved with two lions and a minor god on the monument (Sevin 2003: 186-7). 


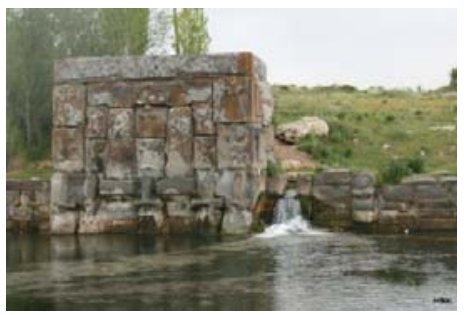

Picture 2: Eflatunpinar Hittite Monument

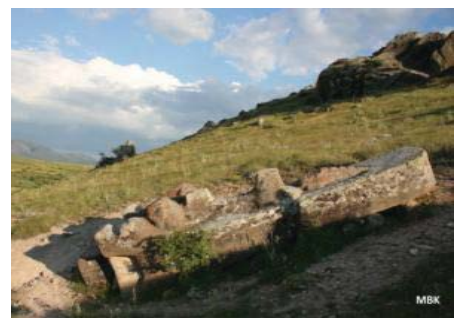

Picture 3: Wolf's Cradle (Büyükkafalı 2013)

\subsection{Kubad Abad Palace}

Kubad Abad was the summer residence of Seljuk sultans on the West coast of Lake Beysehir, at the foot of Anamas Mountain Ridge. Famous Seljukian historian Ibn-i Bibi stated that Seljuk Sultan Alaeddin Keykubat visited western shores of the lake while he was travelling from Kayseri to Antalya via Konya and was fascinated with the scenery of the land and lake and decreed the construction of a summer palace (Arık 2000: 43). Excavations are conducted in the site by Ruchan Arık in summers.

\section{Natural Beauties on Via Sebaste}

Anyway, Lake Beysehir is a natural beauty itself and Via Sebaste surrounds the beauties of the lake. Every meter of this road meets the demands of different types of visitors. A visitor can watch the famous sunset from any place around the lake at any time of the year, in addition to sunset combination of Taurus Mountains with the lake is worth seeing both in winters and in summers.

\subsection{Stork Colonies: Yesildag-Adakoy}

Yesildag and Adakoy are small Anatolian towns $30 \mathrm{~km}$ away from Beysehir. They are on the Side route of Via Sebaste. Suitable places for the storks are the two cemeteries of the towns (Picture 4). Because there are a lot of old juniper trees in the cemeteries and these trees are ideal for the storks to build their nests. First groups of storks arrive here in early April and they breed here. Flying practices of stork chicks in the air all together are watched by a lot of people. 76 stork nests are used by the storks in 2013 summer. Furthermore, there is a camping area $7 \mathrm{~km}$ north of these colonies by the lake.

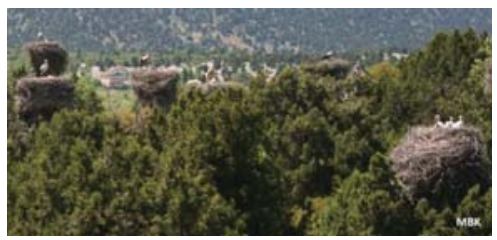

Picture 4: Stork Colony (Büyükkafalı 2013) 


\subsection{Pinargozu Cave}

Pinargozu Cave is the longest cave in Turkey with $15 \mathrm{~km}$ length. It is $11 \mathrm{~km}$ away from the western shores of Lake Beysehir (Karaca 2005: 127). A spring flows from the cave all the year. It is on the other branch of Via Sebaste which was supposed to reach Adada. From this cave a visitor can reach Lake Eğirdir and take the St Paul Trail.

\subsection{Islands of Lake Beysehir}

Islands of Lake Beysehir are not known very well since they are situated far away from Beysehir. They are not visible and accessible from the city centre that is why they are not very popular. Among these, on Haciakif Island there are ruins of storages of the Roman Age. Tek Ada (Lonely Island) is just in the North of Haciakif Island and it was surrounded by a wall during Hellenistic Period. A visitor can see the ruins of a church on the top of the island. Helimin Island (Helim's Island) is very close to these islands. There are ruins of large buildings from the time of Seljuk Turks. There is another old church on Keltas Island (Baldstone Island) in the West part of the lake ${ }^{1}$.

Another important island in this part of the lake is Kızkalesi İsland (Girl's Castle Island). It is across Kubad Abad Palace and used as a dockyard and harem of the palace in Seljuk Era. These islands are very suitable for camping activities since they are very close to western shores of the lake. There are small beaches for swimming on the islands and very favourite places for those who are tired of daily routines².

\section{Other Activities Around Lake Beysehir}

\subsection{Bird Watching}

Beysehir and its environs provide chances for bird watching in every season. Bird watching can be conducted by the help of some equipment like binoculars or spotting scopes in most places. But in Beysehir even in the centrum a visitor can do this activity without a special equipment. Storks, mallards, herons, cormorants, gulls, great crested grebes, coots and various birds can be observed even in the Culture Park in the centrum.

\subsection{Angling}

Lake Beysehir offers very suitable places for anglers from early April to October. Its most common fish is carp and very delicious when compared with other carps of other sources.

\subsection{Paragliding}

An area only $5 \mathrm{~km}$ away from Beysehir was prepared for paragliding activities three years ago. Take off area is just above a famous picnic area and is becoming very popular among paragliding pilots.

\subsection{Photographers Meeting}

Photographers meeting is organised by Beysehir Municipality every spring. Both amateur and professional photographers meet in Beysehir for a couple of days to take the most beautiful pictures of the region. It has already been a very important event in the photographers' calendar.

\subsection{Beysehir Culture, Art, Tourism and Lake Festival}

Beysehir Culture, Art, Tourism and Lake Festival is held in Beysehir in July for a week. Tens of thousands of people meet in the festival area and participate in the activities. It is now the biggest festival of the Central Anatolia.

\section{Conclusion and Suggestions}

Via Sebaste, built in 6 B.C is one of the Roman Roads in Anatolia. Parts of the road around Lake Beysehir connect the

\footnotetext{
1 For further information about ancient history of Haciakif, Tek, Helimin and Keltas islands see; Bahar, 2008: 235-254.

2 For the total number of islands in Lake Beysehir see; Eyüboğlu, 1979: 80-83; Alperen, 2001: 11-13.
} 
natural and historical beauties mentioned above. These kinds of beauties and historical diversity are not available on the similar trekking routes. Local people whose main stay is generally fishing are going to earn much from tourists when this road is opened to tourism. The studies which have to be conducted to use this road for tourism purposes are;

- Exact route of Via Sebaste should be determined on the land. Survived parts of original road should be revealed. A new route based on Via Sebaste should be established.

- At least two village rooms ${ }^{3}$ have to be re-organised and restored on the route. Villages should be determined carefully by considering their position on the route.

- Original Mile Stones of Via Sebaste showing the distance from Antiocheia (Yalvac) should be found and demonstrated on the route and the inscriptions should be translated into Turkish and other languages.

- Imitations of mile stones should be erected on the route showing the distance from Beysehir.

- Paths should be built on the route by using natural materials.

- Some signboards should be prepared to inform the visitors about the plants of the region.

- Some maps should be prepared on the route to show where the visitor is.

- Signboards for giving information about the water birds of the lake should be prepared along the route.

- Some places should be determined for fishing and these places should be prepared for this purposes.

- Camping areas on the islands should be prepared and essential precautions should be taken against forest fire.

- Suitable boats should be determined for the transportation to the islands and enough life vests should be provided.

- Stork colonies or some of the stork nests should be broadcasted by webcams in order to attract the attention of the bird watchers.

- Places of villagers producing traditional dairy products should be shown on the maps in order to meet them with the visitors for selling their products.

\section{References}

Alperen, B., (2001). Beyşehir ve Tarihi. Konya: Büyük Sistem Dershanesi Matbaası.

Arık, R., (2000). Kubad Abad. İstanbul: Türkiye İ̧̧ Bankası Kültür Yayınları.

Bahar, H., (2006). Konya-Karaman İlleri ve İlçeleri 2004 Yılı Yüzey Araştımaları. 23. Araştırma Sonuçları Toplantısı. 1, 30 Mayıs-1 Haziran 2005, 95-106.

Bahar, H., (2008). Konya-Karaman Yüzey Araşıırmaları. 25. Araşıırma Sonuçları Toplantısı. 28 Mayıs-1 Haziran 2007, 235-254.

Cronin, H. S. (1902). First Report of Journey in Pisidia, Lykaonia and Pamphylia. JHS, 22, 94-125.

Darga M., (1992). Hitit Sanatı, İstanbul: Akbank Kültür ve Sanat Yayınları.

Erdoğan, N., (2003). Çevre ve (eko)turizm. Ankara: Genel Yayın ve Dağıtım.

Eyüboğlu, B., (1979). Dünden Bugüne Beyşehir. Konya: Kuşak Ofset.

Karaca, V., (2005). Belgelerle Yenişar (1. Baskı). Isparta: Kardelen Sanat Yayınları.

Konyalı, İbrahim H. (1991). Abideleri ve Kitabeleri ile Beyşehir Tarihi. Erzurum: Fen Edebiyat Fakültesi Ofset Tesisleri.

Levick, B. (1965). Two Inscriptions from Pisidian Antioch. AS, 15, 53-62.

Levick, B. (1967). Roman Colonies in Southern Asia Minor. Oxford: Clarendon Pres.

Mitchell, S. (1995). Anatolia Land, Man and Gods in Asia Minor. New York: Clarendon Press.

Ramsay, W. M. (1916). Colonia Caesarea (Pisidian Antioch) in the Augustan Age. JRS. 6, 83-134.

Ramsay, W. M. (1920). Military Operations on the North Front of Mount Taurus. JHS. 40, 89-112

Ramsay, W. M. (1924). Studies in the Roman Province Galatia: VI. Some Inscriptions of Colonia Caessarea Antiokheia. JRS, 14, $172-$ 205.

Robinson, D. M. (1924). A Prelimenary Report on the Excavations at Pisidian Antioch and at Sizma. AJA, 28 (4), 435-444.

Sevin, V.,(2003). Anadolu Arkeolojisi. İstanbul: Der Yayınları.

Yegül, Fikret K. 2009. "Anadolu Su Kültürü: Türk Kültürü ve Yıkanma Geleneğinin Kökleri ve Geleceğï" Anatolia, c XXXXV, pp 99-118.

http://www.ecotourism.org/book/how-ecotourism-different-nature-tourism-sustainable-tourism-responsible-tourism (Accessed 05 June 2013)

\footnotetext{
3 Village Rooms: They are the rooms in the villages in which the villagers meet or host their visitors. Generally there are more than one room in every village in Anatolia. Visitors do not pay for dining and accommodation and there is no time limit for staying. These rooms were very active $20-30$ years ago due to lack of transportation possibilities. They were the symbols of Anatolian-Turkish hospitality.
} 